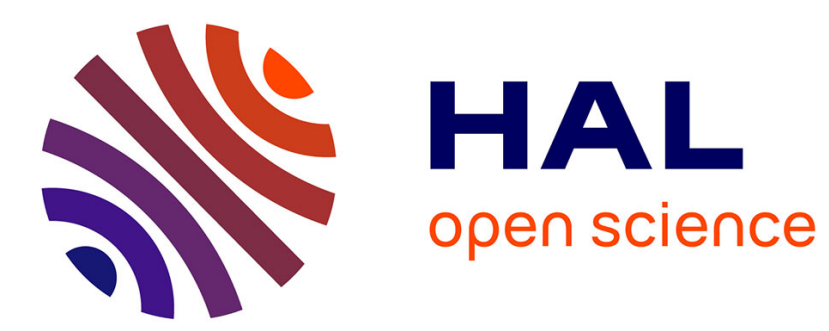

\title{
ATOM-PROBE SPECTROSCOPY OF FIELD ADSORBED He AND Ne
}

\author{
N. Ernst, W. Drachsel, Y. Li, G. Bozdech, J. Block
}

\section{To cite this version:}

N. Ernst, W. Drachsel, Y. Li, G. Bozdech, J. Block. ATOM-PROBE SPECTROSCOPY OF FIELD ADSORBED He AND Ne. Journal de Physique Colloques, 1986, 47 (C7), pp.C7-7-C7-9. 10.1051/jphyscol:1986702 . jpa-00225891

\section{HAL Id: jpa-00225891 https://hal.science/jpa-00225891}

Submitted on 1 Jan 1986

HAL is a multi-disciplinary open access archive for the deposit and dissemination of scientific research documents, whether they are published or not. The documents may come from teaching and research institutions in France or abroad, or from public or private research centers.
L'archive ouverte pluridisciplinaire HAL, est destinée au dépôt et à la diffusion de documents scientifiques de niveau recherche, publiés ou non, émanant des établissements d'enseignement et de recherche français ou étrangers, des laboratoires publics ou privés. 
ATOM-PROBE SPECTROSCOPY OF FIELD ADSORBED He AND $\mathrm{Ne}^{(1)}(2)$

\author{
N. ERNST, W. DRACHSEL, Y. LI*, G. BOZDECH and J.H. BLOCK \\ Fritz-Haber-Institut der Max-Planck-Gesellschaft, \\ Faradayweg 4-6, D-1000 Berlin 33, F.R.G.
}

\title{
SUMMARY
}

An electric field of the order of volts per Angström applied to the emitter-tip in a field-ion microscope induces the adsorption of He and $\mathrm{Ne}$ on metal surfaces at temperatures above $80 \mathrm{~K} / 1 /$. To contribute to an improved understanding of this field enhanced binding, two experimental methods including probe-hole field ion microscopy are applied:

(a) pulsed LASER induced (thermal) field desorption with subsequent time-of-flight mass analysis of the ions $/ 2 /$ and

(b) electron-stimulated field desorption of adsorbates as singly and multiply charged ions, which are mass analysed in a magnetic sector field and energy analysed in a retarding potential filter lens $/ 3 /$.

With field strength values ranging approximately between $3 \mathrm{~V} / \AA$ and $5 \mathrm{~V} / \AA$ the yields of desorbed ions are measured as a function of surface temperature and of retarding voltage. Yield vs. temperature measurements display similar behaviour using either technique; the measured curves reflect the temperature dependence of the coverage of $\mathrm{He}$ and $\mathrm{Ne}$ adsorbed on selected W-surface atoms. Desorption energy values of both species increase from $120 \mathrm{meV}$ to $260 \mathrm{meV}$ as the local field strength is raised from 0.6 to 0.9 of the $80 \mathrm{k}$ evaporation field strength (fig.1). The analysis of retardation curves enables a determination of binding distances as a function of field strength (fig.2). The experimental data are compared to results of recent quantum mechanical calculations of Kreuzer and Nath $/ 4 /$ as well as to the experimental and theoretical results of Tsong et al.

(1) Preliminary report

(2) Supported by the Deutsche Forschungsgemeinschaft, sfb 6/86

*On leave from Dalian Institut of Chemical Physics, Chinese Academy of Sciences, Dalian, P.R. China 


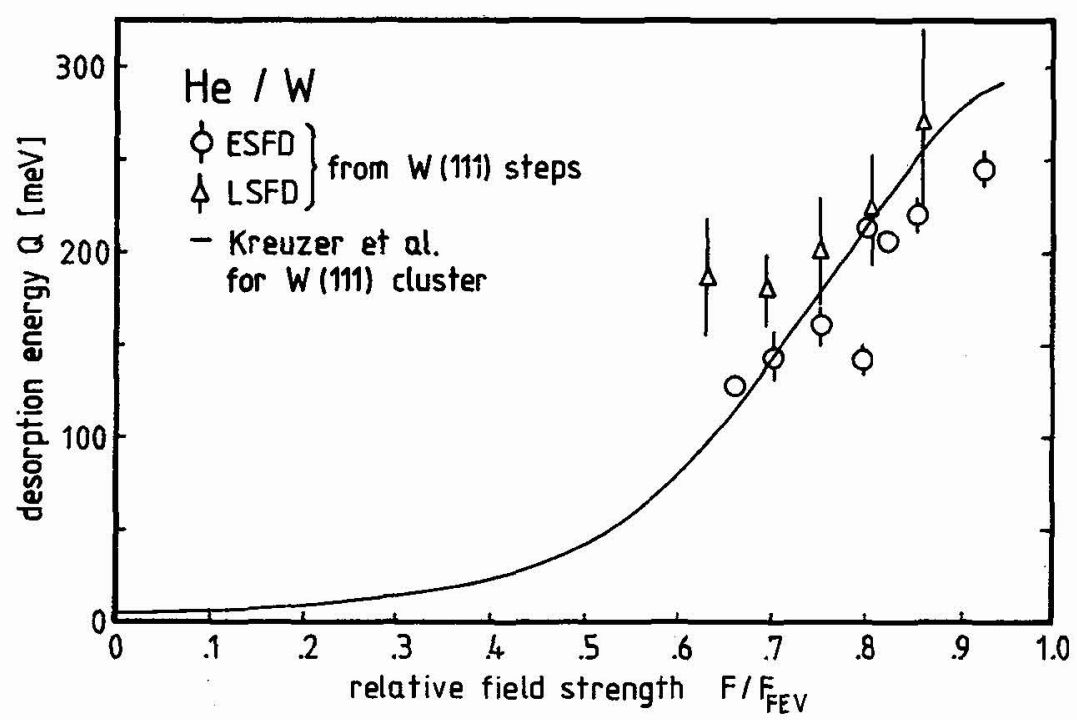

Fig. 1 - Desorption energy $Q$ of field adsorbed helium atoms as a function of local field strength. F is scaled to the low temperature evaporation field $F_{F E V}$ of $c a .55 \mathrm{~V} / \mathrm{nm}$. Circles and triangles represent data obtained by fitting measured temperature dependencies of desorbed ion yields using a volmer adsorption model (mobile adatoms, hard bal1s). Desorption of adsorbed $\mathrm{He}$ as $\mathrm{He}^{+}$was either initiated by electrons (ESFD) or by a laser induced temperature pulse (LSFD). The full line was calculated by Kreuzer and Nath using a tight binding cluster approach $/ 4 /$.

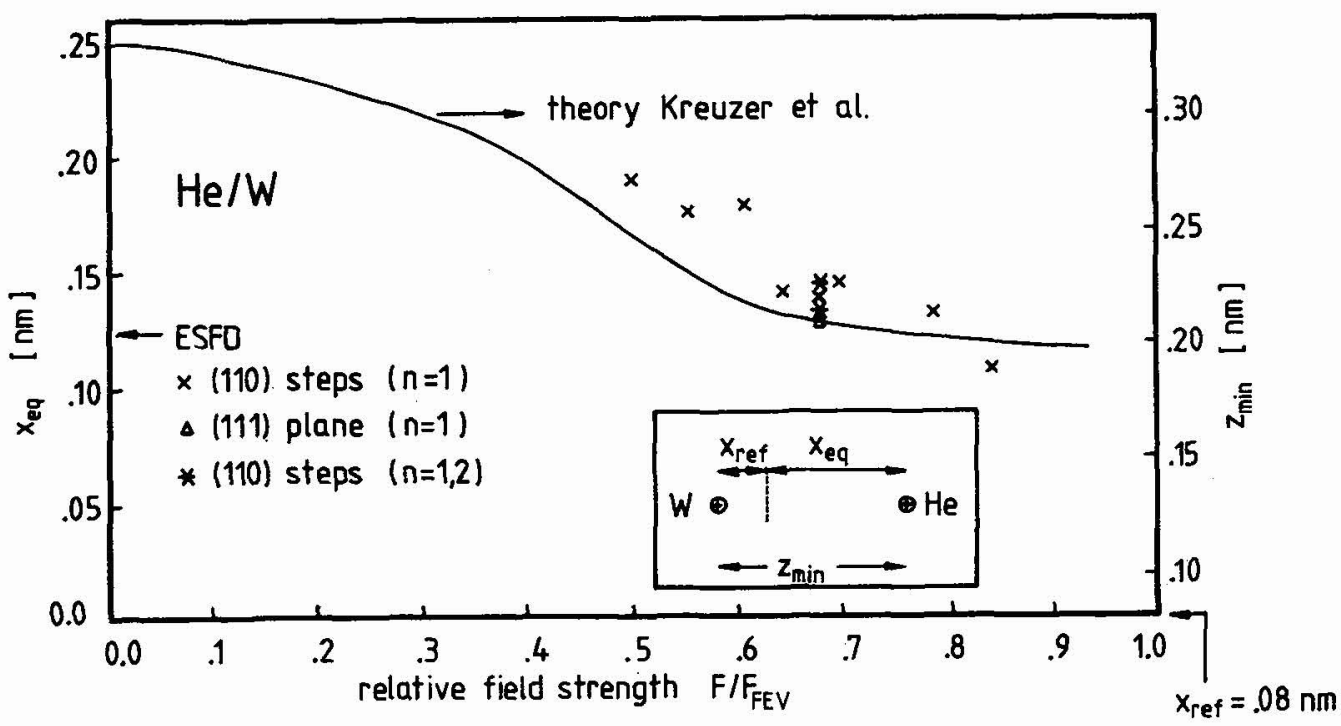




\section{REFERENCES}

/1/ Miiller, E.W., and Tsong, T.T., Progr. Surf. Sci. 4 (1974) 1.

/2/ Drachsel, W., Block, J.H., and Viswanathan, B., sporinger Ser. in Chem. Phys. 33 (1983) 221.

13/ Ernst, N., Phys. Rev. Lett. 45 (1980) 1573.

/4/ Kreuzer, H.J., and Nath, K., these proceedings.

/5/ Gies, P., and Gerhardts, R.R., Phys. Rev. B. 33 (1986) 982.

- Fig. 2 - Equilibrium distance of a field adsorbed helium atom as a function of relative field strength (low temperature evaporation field strength $\left.F_{F E V} \approx 55 \mathrm{~V} / \mathrm{nm}\right)$. The distance scale $x_{e q}$ on the left applies to the experimental results obtained by retarding potential analysis of singly as well as doubly charged ESFD helium ions. The $z_{\text {min }}$-scale on the right is related to the theoretical curve of Kreuzer and Nath /4/. Note the difference between reference-zero positions $x_{\text {ref }}$ shown in the inlet. $x_{\text {eq }}$-data measured on $w(111)$ were fitted to the theoretical result giving $x_{\text {ref }}=0.08 \mathrm{~nm}$, being in good agreement with values calculated for the image plane position at a strongly charged jellium surface $/ 5 /$. 